\title{
BIOINDICATION OF TRACE METAL POLLUTION IN THE ATMOSPHERE OF BAKU CITY USING LIGUSTRUM JAPONICUM, OLEA EUROPEA, AND PYRACANTHA COCCINEA LEAVES
}

\author{
Naglaa Youssef ${ }^{\mathrm{a}, \mathrm{b}}$, Bernd Markert ${ }^{\mathrm{c}}$, Elshad Gurbanov ${ }^{\mathrm{a}}$, Haciyeva Sevnic ${ }^{\mathrm{d}}$, \\ Simone Wünschmann ${ }^{\mathrm{c}}$ \\ ${ }^{a}$ Department of Botany, Faculty of Biology, Baku State University, Baku, Azerbaijan \\ ${ }^{b}$ Department of Botany, Faculty of Sciences, Sohag University, Sohag, Egypt \\ ${ }^{c}$ Environmental Institute of Scientific Neworks (EISN-Institute), Fliederweg 17, 49733 Haren, Germany \\ ${ }^{d}$ Department of Ecological Chemistry, Faculty of Chemistry, Baku State University, Baku, Azerbaijan \\ Received 28 Sep. 2012; accepted 9 May 2013
}

\begin{abstract}
The leaves of Ligustrum japonicum (Oleaceae), Olea europaea (Oleaceae), and Pyracantha coccinea (Rosaceae) were evaluated with the aim of using them as bioindicators for trace metal contamination in Baku city, Azerbaijan, one of the most highly polluted cities worldwide. These species of trees are the most abundant in urban and rural areas of Azerbaijan, because of high tolerance against climatic influences due to their modesty and adaptability. Concentrations of $\mathrm{Cd}, \mathrm{Cr}, \mathrm{Cu}, \mathrm{Fe}$, and $\mathrm{Pb}$ were determined in the leaves by AAS method. The samples were collected at three locations with different degrees of trace metal pollution (industrial, high traffic, and reference [botanical garden] site). The highest element concentrations were detected at sites of high traffic. Up to 70 times higher $\mathrm{Pb}$ concentrations could be found in the leaves of the trees that reflect the known $\mathrm{Pb}$ problem around Baku. The results presented give a first impression of a correlation between the degree of trace metal contamination in the environment and the trace metal concentration in the leaves of L. japonicum and O. europaea.

Keywords: air pollution, trace metals, environmental monitoring, leaves, bioindicators, Baku, Azerbaijan.

Reference to this paper should be made as follows: Youssef, N.; Markert, B.; Gurbanov, E.; Sevnic, H.; Wünschmann, S. 2014. Bioindication of trace metal pollution in the atmosphere of Baku city using Ligustrum japonicum, Olea europea, and Pyracantha coccinea leaves, Journal of Environmental Engineering and Landscape Management 22(1): 14-20. http://dx.doi.org/10.3846/16486897.2013.804828
\end{abstract}

\section{Introduction}

Air pollution is an offensive risk and can be a genuine health hazard to humans as well as to animals, plants, and microorganisms. Plant tissues have shown to behave as an effective indicator of atmospheric pollution (e.g. Markert et al. 2003; Wolterbeek et al. 2010). Vegetation is an acceptable indicator of pollution impact to its vicinity, because plants have the ability to accumulate or reject trace metals so that their metal levels correlate to those in the air. The effect observed is a time-averaged result, which will be - in most cases more reliable than that obtained from direct determination of the pollutant concentrations in air for a short period. Hence, analyzing plant tissues can often produce better results in terms of sensitivity and reproducibility (Lau, Luk 2001). Some plant species are especially useful as biological indicators to assess air pollution because of their global distribution (e.g. Kardel et al. 2010). A lot of plant species have already been applied as bioindicator species (Baycu et al. 2006; Celik et al. 2005; Fraenzle et al. 2012; Markert et al. 2003; 2008; Mingorance, Oliva 2006; Youssef 2012). The contaminants can deposit on and in the surface of leaves (Salma et al. 2001) and increase their harmful effects on human health (Temesi et al. 2003). Accumulation of heavy metals causes chronic damage to ecosystems and must be carefully observed and monitored taking into account uptake, movement, and effects of the contaminants on both the environment and its biota (Fraenzle et al. 2012; Markert et al. 2008; Mingorance, Oliva 2006; Morselli et al. 2004).

The aim of the present study is to investigate the pollution levels of $\mathrm{Cd}, \mathrm{Cr}, \mathrm{Cu}, \mathrm{Fe}$, and $\mathrm{Pb}$ using leaves of plant species, such as Ligustrum japonicum, Olea

Corresponding author: Simone Wünschmann

E-mail: wuenschmann@eisn-institute.de 
europaea, and Pyracantha coccinea from three different sites in and around Baku (the capital of Azerbaijan). Baku has been discussed as one of the highest polluted cities of the world (Luck 2008), being polluted by emissions of oil drillings. Ismailov and Akhoun-Zade (1999) reported that especially during 1991-1994, serious environmental problems were caused by petrochemical industry, power plants, metallurgical, and building materials industries situated in Baku. Important contaminants have been hydrocarbons through $1,665,000$ tons/y of emission from oil refineries in Baku. After Sawidis et al. (2011) the environmental lead pollution is directly related to the density of traffic. The main part of the total vehicle fleet up to $65 \%$ is located in the city of Baku, which significantly affects the ecological background of the city.

The results of this study should answer the scientific question whether plant leaves of L. japonicum, $O$. europaea, and $P$. coccinea can be used as bioindicators for environmental pollution observation and control in Baku city. The three species under investigation meet the requirements of bioindicators: wide distribution, high abundance, accumulation of pollutants, easy to collect, simple identification and cultivation, and analytical fitness. The studied elements are common pollutants in the air, especially in industrial cities as Baku characterized by large petroleum industry and by high density of traffic (Babayeva 2002). The results are especially of interest as preliminary baseline data for environmental air pollution of Baku derived from tree leaves.

\section{Materials and methods}

\subsection{Sampling of plant leaves}

Leaves of the evergreen trees L. japonicum (Oleaceae), $P$. coccinea (Rosaceae), and O. europaea (Oleaceae) were selected in three different areas in and around Baku (Fig. 1): (1) industrial zone of Baku (Absheron peninsula), (2) region of Baku airport with high traffic, and (3) botanical garden of Baku State University as reference site (10 km distance to pollution sources). From each sampling point, leaves of five trees per species (all in between 30 and 40 years) were taken from April to June 2012. Leaves of four different branches of each tree were sampled at a height of 1.5-2 $\mathrm{m}$ above the ground. From each branch three shoots were chosen. The sampling procedure followed the method after Sawidis et al. (2011). Care was given to avoid the collection of leaves characterized by insect infestation, presence of honeydew, bird dropping, pesticide treatment, chlorosis or necrosis, coarse, and anomalous dust cover. The collected leaves (about $30 \mathrm{~g}$ per sample) were placed in paper envelopes immediately after collection and dried in the laboratory.

\subsection{Analytical procedure}

After drying and homogenization, the samples were placed in polythene bags and stored in a refrigerator at $4{ }^{\circ} \mathrm{C}$. One gram of each sample was digested in an open quartz tube and $10 \mathrm{ml}$ of concentrated $\mathrm{HNO}_{3}$ (Merck) was added to each sample and the mixture was left at room temperature overnight. In the further course, the

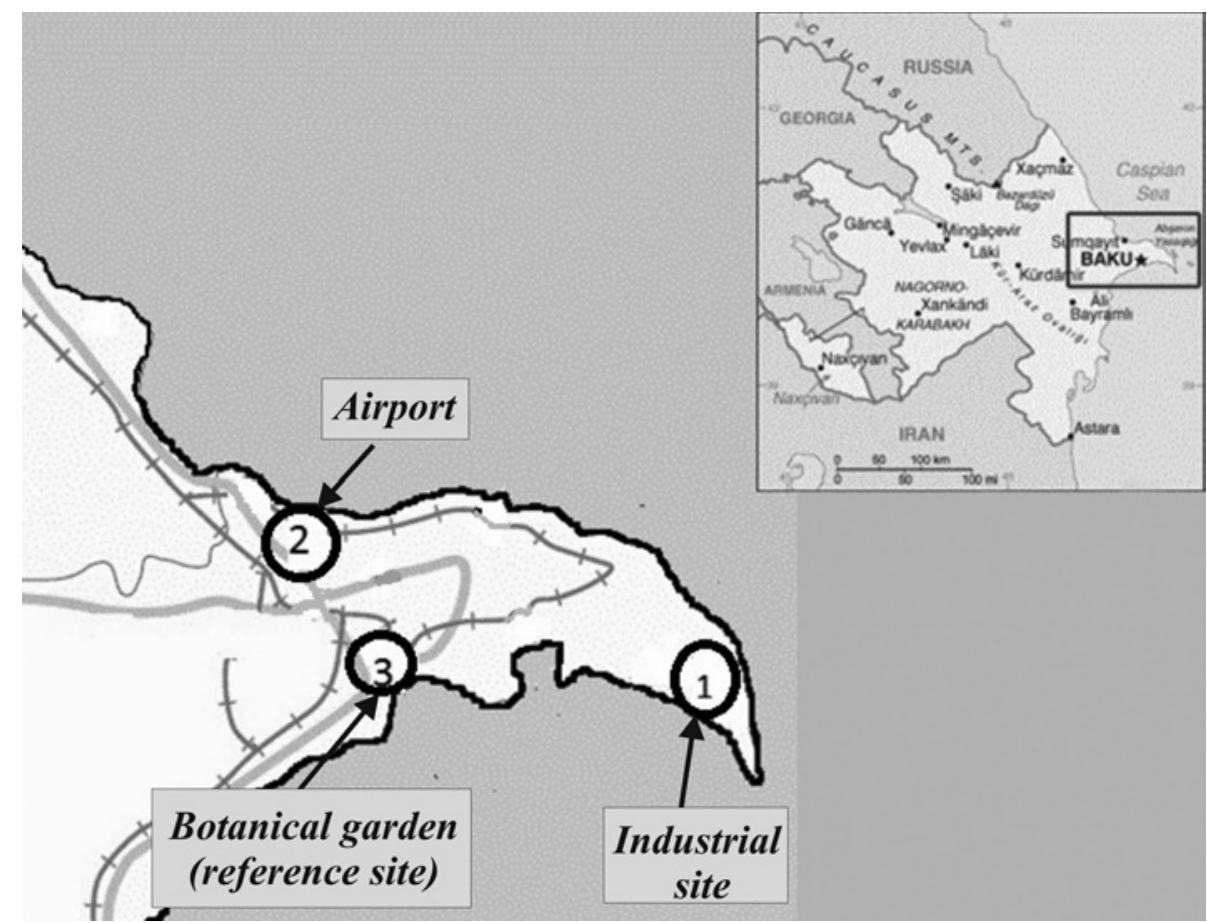

Fig. 1. Sampling locations of tree leaves in Baku, Azerbaijan 
samples were heated at $50{ }^{\circ} \mathrm{C}$ for $2 \mathrm{~h}$ and subsequently heated at $160{ }^{\circ} \mathrm{C}$ for $4 \mathrm{~h}$. The solution was filtered through a Whatman type 589/2 filter and the filtrate was diluted to $25 \mathrm{ml}$ volume with double de-ionized water. These final solutions were analyzed for trace metal concentrations using an Atomic Absorption Spectrophotometer 850 (flame atomization, Perkin Elmer) at the Analysis Center of the Geological Institute at Azerbaijan, National Academy of Science. The quality controls of instrumental measurements were performed by using the National Standard of Azerbaijan BZ No.7-95, O. europaea. Statistical analyses were done by using Excel, Origin 6, and SPSS 11.5.

\section{Results and discussion}

The detected concentrations of $\mathrm{Cd}, \mathrm{Cr}, \mathrm{Cu}, \mathrm{Fe}$, and $\mathrm{Pb}$ in tree leaves from each sampling area are summarized in Table 1. Element specific concentrations are represented in Figures 2-6.

\subsection{Cadmium}

The leaves of $L$. japonicum showed the highest $\mathrm{Cd}$ amount up to $0.514 \pm 0.13 \mathrm{ppm}$ dry wt at site 2 in relation to the other tree species (traffic area, see Fig. 2). In general the $\mathrm{Cd}$ distribution pattern demonstrates higher $\mathrm{Cd}$ concentrations at the sampling sites 1 (industry) and 2 (traffic) in relation to the reference site (botanical garden). Compared to the average reference concentration for $\mathrm{Cd}$ in plants $(0.03-$ $0.5 \mathrm{ppm}$ dry wt, Markert 1997) the Cd concentrations found do not cause pathological effects to plants.

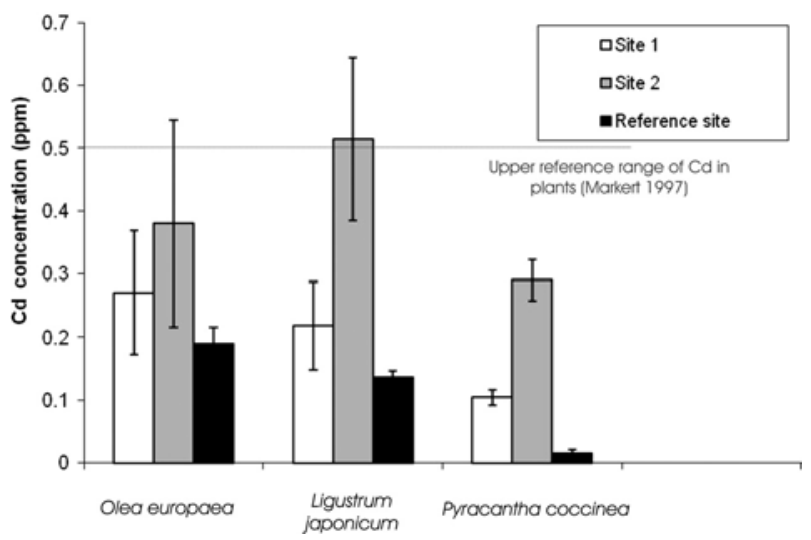

Fig. 2. Cadmium concentrations (ppm dry wt) in the leaves of Olea europaea, Ligustrum japonicum, and Pyracantha coccinea from different studied sites (site 1: industry; site 2: traffic; reference site: botanical garden)

\subsection{Chromium}

The leaves of $O$. europaea and $L$. japonicum represented much higher levels of $1.6-9$ ppm dry wt in relation to the average reference concentration for $\mathrm{Cr}$ in plants (0.2-1 ppm dry wt, Markert 1997). However, the Cr concentrations in the leaves of $P$. coccinea taken from all three sampling sites matched the reference range of $\mathrm{Cr}$ contents in plants (up to $1 \mathrm{ppm}$ dry wt).

\subsection{Copper}

The leaves of $O$. europaea showed the highest $\mathrm{Cu}$ amounts of up to $84 \mathrm{ppm}$ dry wt at the sampling site 2 (traffic) and up to 73 ppm dry wt at sampling site 1 (industry) (Fig. 4). After Markert (1997) the average reference concentrations of $\mathrm{Cu}$ in plants differ between 2 and $20 \mathrm{mg} / \mathrm{l}$. These values correspond with the $\mathrm{Cu}$

Table 1. Comparison of $\mathrm{Cd}, \mathrm{Cr}, \mathrm{Cu}, \mathrm{Fe}$, and $\mathrm{Pb}$ concentrations in leaves of Olea europaea, Ligustrum japonicum, and Pyracantha coccinea from different studied sites

\begin{tabular}{|c|c|c|c|c|c|c|}
\hline Plant species & Site & $\underset{\text { dry wt }}{\text { Cd, ppm } \pm \text { sd }}$ & $\begin{array}{l}\mathrm{Cr}, \mathrm{ppm} \pm \mathrm{sd} \\
\text { dry wt }\end{array}$ & $\underset{\text { dry wt }}{\mathrm{Cu}, \mathrm{ppm} \pm \mathrm{sd}}$ & $\underset{\text { dry wt }}{\mathrm{Fe}, \mathrm{ppm} \pm \mathrm{sd}}$ & $\begin{array}{c}\mathrm{Pb}, \mathrm{ppm}_{\mathrm{dry}} \pm \mathrm{sd} \\
\text { drt }\end{array}$ \\
\hline \multirow{3}{*}{ Olea europaea } & Site 1: industrial zone & $0.27 \pm 0.10$ & $9 \pm 3$ & $73 \pm 14$ & $273 \pm 86$ & $221 \pm 31$ \\
\hline & $\begin{array}{l}\text { Site 2: high traffic } \\
\text { (airport) }\end{array}$ & $0.38 \pm 0.16$ & $7 \pm 2$ & $84 \pm 18$ & $188 \pm 55$ & $282 \pm 40$ \\
\hline & $\begin{array}{l}\text { Site 3: reference site, } \\
\text { botanical garden }\end{array}$ & $0.19 \pm 0.03$ & $4 \pm 1$ & $21 \pm 4$ & $165 \pm 66$ & $70 \pm 13$ \\
\hline \multirow{3}{*}{$\begin{array}{l}\text { Ligustrum } \\
\text { japonicum }\end{array}$} & Site 1: industrial zone & $0.22 \pm 0.07$ & $4 \pm 0.70$ & $33 \pm 9$ & $232 \pm 55$ & $257 \pm 24$ \\
\hline & $\begin{array}{l}\text { Site 2: high traffic } \\
\text { (airport) }\end{array}$ & $0.54 \pm 0.13$ & $4 \pm 1$ & $45 \pm 10$ & $250 \pm 33$ & $341 \pm 73$ \\
\hline & $\begin{array}{l}\text { Site 3: reference site, } \\
\text { botanical garden }\end{array}$ & $0.14 \pm 0.01$ & $1.63 \pm 0.35$ & $6 \pm 1$ & $170 \pm 31$ & $99 \pm 19$ \\
\hline \multirow{3}{*}{$\begin{array}{l}\text { Pyracantha } \\
\text { coccinea }\end{array}$} & Site 1: industrial zone & $0.10 \pm 0.01$ & $0.47 \pm 0.15$ & $14 \pm 3$ & $98 \pm 24$ & $60 \pm 11$ \\
\hline & $\begin{array}{l}\text { Site 2: high traffic } \\
\text { (airport) }\end{array}$ & $0.29 \pm 0.03$ & $0.39 \pm 0.13$ & $21 \pm 5$ & $122 \pm 19$ & $106 \pm 13$ \\
\hline & $\begin{array}{l}\text { Site 3: reference site, } \\
\text { botanical garden }\end{array}$ & $0.02 \pm 0.01$ & $0.23 \pm 0.02$ & $3 \pm 0.79$ & $135 \pm 23$ & $53 \pm 9$ \\
\hline
\end{tabular}




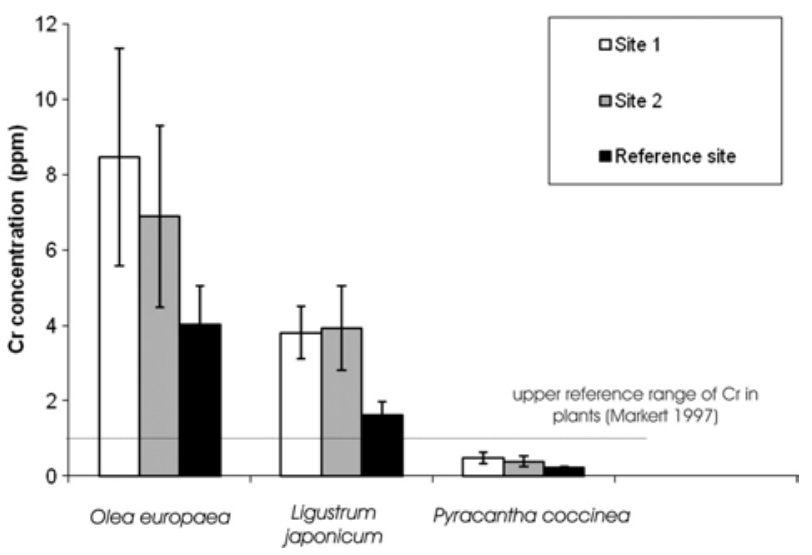

Fig. 3. Chromium concentrations (ppm dry wt) in the leaves of Olea europaea, Ligustrum japonicum, and Pyracantha coccinea from different studied sites (site 1: industry; site 2: traffic; reference site: botanical garden)

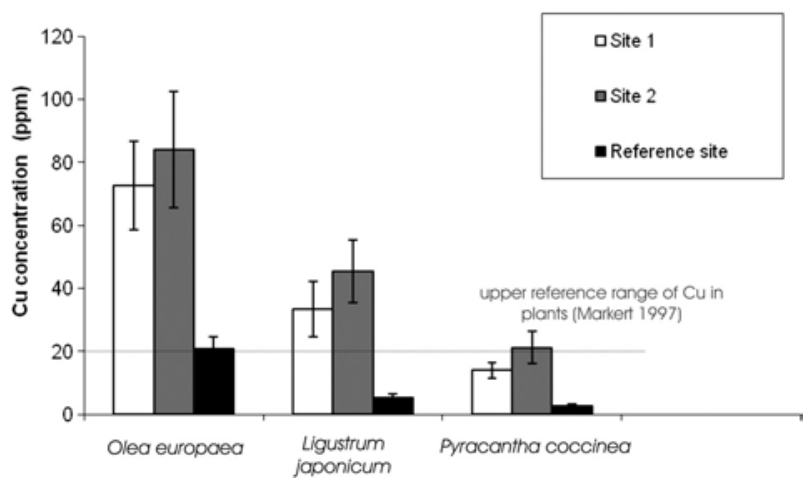

Fig. 4. Copper concentrations (ppm dry wt) in leaves of Olea europaea, Ligustrum japonicum, and Pyracantha coccinea from different studied sites (site 1: industry; site 2: traffic; reference site: botanical garden)

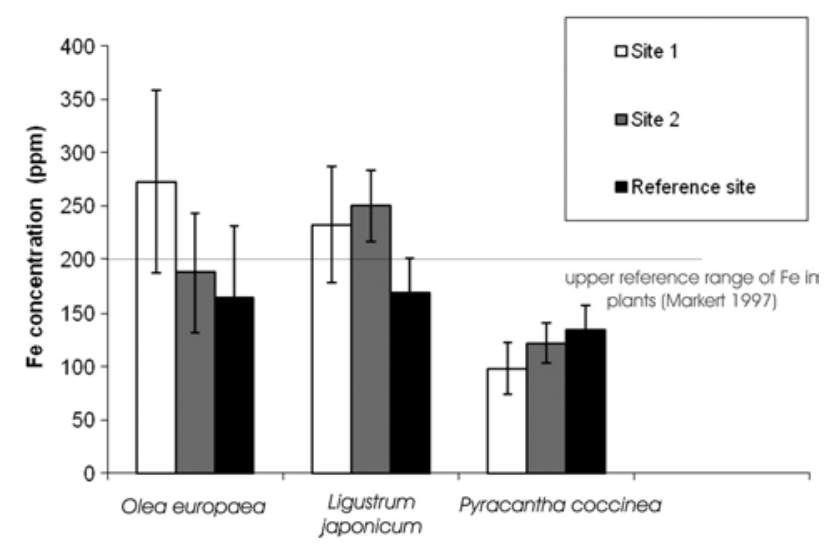

Fig. 5. Iron concentrations (ppm dry wt) in the leaves of Olea europaea, Ligustrum japonicum, and Pyracantha coccinea from different studied sites (site 1: industry; site 2: traffic; reference site: botanical garden)

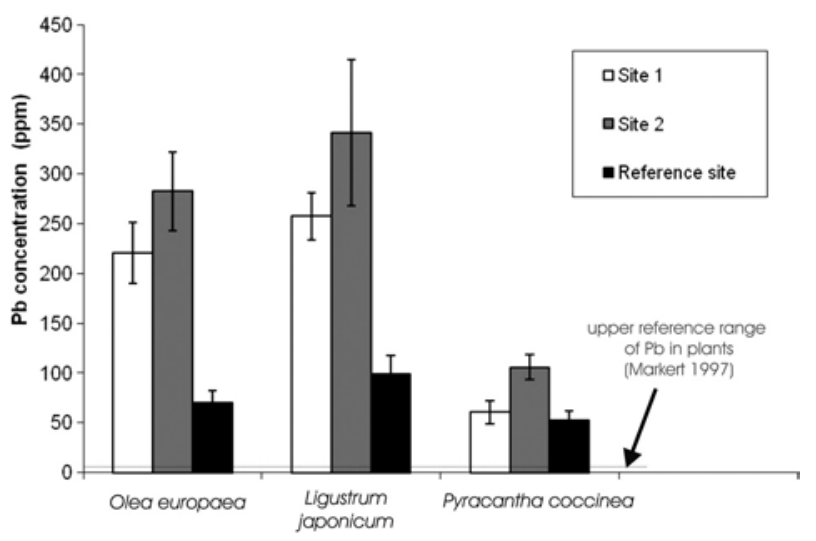

Fig. 6. Lead concentrations (ppm dry wt) in the leaves of Olea europaea, Ligustrum japonicum, and Pyracantha coccinea from different studied sites (site 1: industry; site 2: traffic; reference site: botanical garden)

concentrations evaluated in all three leave species collected from the reference site (botanical garden; up to $21 \mathrm{ppm}$ dry wt) and with the $\mathrm{Cu}$ concentrations measured in the leaves of $P$. coccinea at all studied places.

The $\mathrm{Cu}$ concentrations in the leaves of $O$. europaea and $L$. japonicum show up to four times higher $\mathrm{Cu}$ concentrations for the sampling points 1 and 2 compared to the "normal" values between 2 and $20 \mathrm{mg} / \mathrm{l}$.

\subsection{Iron}

The leaves of $O$. europaea and $L$. japonicum showed higher $\mathrm{Fe}$ concentrations up to $273 \mathrm{ppm}$ dry weight related to the leaves of $P$. coccinea (up to $135 \mathrm{ppm}$ dry wt at the reference site, Fig. 5). According to Markert (1997) the average reference concentration for $\mathrm{Fe}$ in plants ranges from 5 to $200 \mathrm{ppm}$ dry wt. These values corresponded with the Fe concentrations found in the leaves of $P$. coccinea at all samplings sites and with the $\mathrm{Fe}$ concentrations found in the leaves of $O$. europaea and $L$. japonicum collected from the reference site (botanical garden). The leaves of $O$. europaea taken from the sampling site no. 1 and the leaves of $L$. japonicum taken from the sampling sites 1 and 2 represented up to $30 \%$ higher Fe concentrations.

\subsection{Lead}

All evaluated $\mathrm{Pb}$ concentrations in the leaves of $O$. europaea, L. japonicum, and $P$. coccinea exceeded to a considerable degree the average reference concentration in plants of 0.1-5 ppm dry wt (Markert 1997). Figure 6 demonstrates that the $\mathrm{Pb}$ concentrations of the reference sites (botanical garden) were lower compared to site 1 (industry) and 2 (traffic). But these concentrations are much higher than the "normal" average value of $0.1-5 \mathrm{ppm}$ dry wt given by Markert (1997). Values up to around $350 \mathrm{ppm}$ dry wt in the 
leaves of L. japonicum could be detected at the sampling site 2 (traffic). Figure 6 also demonstrates that the leaves of the tree species $O$. euopaea and $L$. japonicum accumulate $\mathrm{Pb}$ in much higher concentrations compared to the leaves of $P$. coccinea.

\subsection{Comparison of all chemical elements to each other}

In summary, as expected, both sites (industry (1) and high traffic (2)) show higher element concentrations in comparison to the reference site (botanical garden site (3)). In case of $\mathrm{Cd}$ concentrations, all values measured at the sampling sites seem to be within a tolerable range. After Markert (1997) the average reference concentration of $\mathrm{Cd}$ in plants differs between 0.03 and $0.5 \mathrm{ppm}$ dry wt. In the present study, the highest $\mathrm{Cd}$ concentration could be detected with $0.514 \mathrm{ppm}$ dry wt in the leaves of $L$. japonicum. Based on these results, there is probably no significant $\mathrm{Cd}$ pollution in the urban region of Baku. The same could be found for Fe concentrations in the leaves studied. Related to the "normal" average reference concentration of $\mathrm{Fe}$ in plants after Markert (1997) with up to 200 ppm dry wt, the highest $\mathrm{Fe}$ concentration in the present study showed a value of $270 \mathrm{ppm}$ dry wt. So the Fe concentrations in the leaves of the trees $O$. europaea and L. japonicum are slightly increased, but not significantly. The $\mathrm{Fe}$ concentrations in the leaves of $P$. coccinea are absolutely in an acceptable range.

For the elements $\mathrm{Cr}, \mathrm{Cu}$, and especially for $\mathrm{Pb}$ the situation is quite different. It is noticeable that the $\mathrm{Cr}$ and $\mathrm{Cu}$ concentrations in the leaves of $P$. coccinea are quite acceptable according to all studied places. Related to the $\mathrm{Cr}$ and $\mathrm{Cu}$ concentrations in the leaves of the tree species $O$. europaea and $L$. japonicum, with exception for the $\mathrm{Cu}$ concentration in leaves taken from the reference sites, there are higher values compared to the given average reference values of $\mathrm{Cr}$ and $\mathrm{Cu}$ in plants after Markert (1997): up to nine times higher for $\mathrm{Cr}$ concentrations and up to four times higher for $\mathrm{Cu}$ concentrations. The $\mathrm{Pb}$ concentrations detected in all leaves samples reflect a very serious $\mathrm{Pb}$ emission problem in and around the region of Baku. Even the lowest $\mathrm{Pb}$ concentration measured in the leaves of $P$. coccinea at the reference site (botanical garden) showed a 10 times higher $\mathrm{Pb}$ concentration compared to the "normal" average reference concentration of $\mathrm{Pb}$ in plants given by Markert (1997). Especially, the more $\mathrm{Pb}$ contaminated sample regions site 1 (industry) and site 2 (traffic) showed up to 70 times higher $\mathrm{Pb}$ concentrations. The reason for the higher lead values might be the greater use of cars and buses fuelled with leaded gasoline. Industrial and metallurgical processes, as well as the combustion of diesel oil produce the largest emissions of lead. The city's past as a Soviet industrial center has left it as one of the most polluted cities in the world (Luck 2008). At site 1, industrial facilities (chemical, pharmaceutical, metallic, petroleum industry) are randomly distributed in the central parts of the region. They represent, together with city traffic and coal power stations, the sources of various types of pollutants (Mitrovic et al. 2008; Pavlovic et al. 2007). It is known that the main sources of copper and lead pollution are the steel industry and coal combustion (Anagnostatou 2008). These results give an indication that the accumulation of trace metals depend on the traffic, industrial activities, and urbanization levels (Markert et al. 2011; Mingorance, Oliva 2006).

Additionally, the results show that the concentrations of all studied elements in $P$. coccinea tissue were comparable to the given "normal" averaged reference ranged values for plants after Markert (1997) with the exception of $\mathrm{Pb}$. These results give the conclusion that the tree species $P$. coccinea is not applicable for bioindication of air pollution. Unlike that situation, the tree species $O$. europaea and $L$. japonicum demonstrate the effects of urbanization on elemental concentrations in leaves, but the results may also depend on the morphological anatomical parameters of leaves (Kardel et al. 2010).

Nevertheless, there are some general trends in the data which, notwithstanding effects of selective uptake of metal ions by plants, can be used to show that there are different sources of emission/pollution which contribute to metal contents of the leaves, that is, $\mathrm{Pb}$, and $\mathrm{Cr}$ get there from other sources than Fe does (which is quite reasonable), possibly via particles of different sizes and origins or part via soil/ground water, part through atmospheric deposition (total digestion of leaves prior to analysis or complete burning in F-AAS covers both pathways to the leaf). Of course, the three plants differ in both biochemical fractionation behavior (which unfortunately is not yet numerically specified for these three species) when obtaining metal ions from soil and in relative impacts of atmospheric deposition likewise (the leaves are differently thick and "sticky").

\section{Conclusions}

Air pollution with trace metals is a matter of great interest, especially in urban areas (Markert et al. 2011). Monitoring of air quality using plants has been widely applied to detect and to monitor the level, distribution and effect of pollution (Gajic et al. 2009; Markert et al. 2003; Mingorance, Oliva 2006). Although biomonitoring of air quality using plants has been practiced for years in many European countries, it has still not been applied at a satisfactory level, due to different and even opposing results. Trees are very efficient at trapping atmospheric particles, and they play a special role in reducing the level of fine, "high risk" respirable particulates, which have the potential to cause serious 
human health problems. The present primary results on trace metal concentrations in leaves of tree species in and around Baku show that especially, the leaves of $O$. europaea and L. japonicum can be probably used as bioindicators, because of their ability to accumulate the essential elements $\mathrm{Cu}, \mathrm{Cr}$, and Fe. But of highest interest are the $\mathrm{Pb}$ concentrations in the environment. $\mathrm{Pb}$ is a nonessential element and can lead to toxic effects to humans, animals, and plants alike. So, the present study showed that the leaves especially of $O$. europaea and L. japonicum reflect in an excellent way the $\mathrm{Pb}$ status of the environment of Baku.

After Sawidis et al. (2011) the environmental lead pollution is directly related to the density of traffic. The main part of the total vehicle fleet up to $65 \%$ is located in the city of Baku, which significantly affects the ecological background of the city. In addition to the traffic density, industrial activities also tend to increase the concentration. The samples obtained from an industrial area, as well as from urban roadsides, which encounter the highest human activity and vehicular density, had the highest accumulation of the metal concentrations. Most of this contamination can clearly be traced back to motor vehicle traffic emissions.

In general, because the leaves of $O$. europaea and L. japonicum as bioindicators are reflecting the environmental status it would be enriching to join global monitoring programs of air pollution.

In conclusion,

(1) the leaves of O. europaea and L. japonicum have been used for the first time as possible bioindicators for controlling the air pollution in Baku city; they reflect the environmental status;

(2) the leaves of $P$. coccinea are not suitable for bioindication.

\section{Acknowledgements}

This work is a result of cooperation between Baku State University and Analysis Center of the Geological Institute at Azerbaijan, National Academy of Sciences. PD Dr. Stefan Fraenzle is thanked for improving the English of this article.

\section{References}

Anagnostatou, A. V. 2008. Assessment of heavy metals in central Athens and suburbs using plant material. Dissertation. University of Surrey, UK.

Babayeva, S. 2002. Transport and pedestrian communications in the residential quarters of Baku central zone, Urbanizm 2(3): 55-58.

Baycu, G.; Tolunay, D.; Özden, H.; Günebakan, S. 2006. Ecophysiological and seasonal variations in $\mathrm{Cd}, \mathrm{Pb}, \mathrm{Zn}$, and $\mathrm{Ni}$ concentrations in the leaves of urban deciduous trees in Istanbul, Environmental Pollution 143: 545-554.

Celik, A.; Kartal, A. A.; Akdogan, A.; Kaska, Y. 2005. Determining the heavy metal pollution in Denizli
(Turkey) by using Robinio pseudoacacia L., Environment International 31: 105-112.

Fraenzle, S.; Markert, B.; Wuenschmann, S. 2012. Introduction to environmental engineering. New York, Tokyo: Wiley$\mathrm{VCH}$, Weinheim.

Gajic, G.; Mitrovic, M.; Pavlovic, P.; Stevanovic, B.; Djurdjevic, L.; Kostic, O. 2009. An assessment of the tolerance of Ligustrum ovalifolium Hassk to traffic-generated $\mathrm{Pb}$ using physiological and biochemical markers, Ecotoxicology and Environmental Safety 72: 1090-1101.

Ismailov, T.; Akhoun-Zade, F. 1999. Environmental information system in Azerbaijan, assessment report for establishing a national environmental and natural resource information network Compatible with the UNEP/GRID [online], [cited March 2003]. Available from Internet: http://www.grida.no/enrin/htmls/azer.htm

Kardel, F.; Wuyts, K.; Babanezhad, M.; Vitharana, U. W. A.; Wuytack, T.; Potters, G.; Samson, R. 2010. Assessing urban habitat quality based on specific leaf area and stomatal characteristics of Plantago lanceolata L., Environmental Pollution 158: 788-794.

Lau, O. W.; Luk, S. F. 2001. Leaves of Bauhinia blakeana as indicators of atmospheric pollution in Hong Kong, Atmospheric Environment 35: 3113-3120.

Luck, T. 2008. The world's dirtiest cities [online], Forbes [cited November 2010]. Available from Internet: http://www. forbes.com/2008/02/26/pollution-baku-oil-biz-logisticscx_tl_0226dirtycities.html

Markert, B. 1997. Instrumental element and multi-element analysis of plant samples. Methods and applications. Weinheim: Wiley-VCH.

Markert, B.; Breure, A.; Zechmeister, H. (Eds.). 2003. Bioindicators and biomonitors. Principles, concepts and applications. Amsterdam: Elsevier.

Markert, B.; Wuenschmann, S.; Fraenzle, S.; Wappelhorst, O.; Weckert, V.; Breulmann, G.; Djingova, R.; Herpin, U.; Lieth, H.; Schroeder, W.; Siewers, U.; Steinnes, E.; Wolterbeek, B.; Zechmeister, H. 2008. On the road from environmental biomonitoring to human health aspects, monitoring atmospheric heavy metal deposition by epiphytic/epigeic plants: present status and future needs, Environmental Pollution 32(4): 486-498.

Markert, B.; Wuenschmann, S.; Fraenzle, S.; Figueiredo, A. M.; Ribeiro, A. P.; Wang, M. 2011. Bioindication of atmospheric trace metals - with special reference to megacities, Environmental Pollution 159: 1991-1995.

Mingorance, M. D.; Oliva, S. R. 2006. Heavy metals content in $N$. oleander leaves as urban pollution assessment, Environmental Monitoring and Assessment 119: 57-68.

Mitrovic, M.; Pavlovic, P.; Lakusic, D.; Djurdjevic, L.; Stevanovic, B.; Kostic, O.; Gajic, G. 2008. The potential of Festuca rubra and Calamagrostis epigejos for the revegetation of fly ash deposits, Science of Total Environment 407(1): 338-347.

Morselli, L.; Brusoni, B.; Passarini, F.; Bernardi, E.; Francaviglia, R.; Gataleta, L. 2004. Heavy metal monitoring at a Mediterranean natural ecosystem of Central Italy. Trends in different environmental matrixes, Environmental International 30(2): 173-81. 
Pavlovic, P.; Mitrovic, M.; Djurdjevic, L.; Gajic, G.; Kostic, O.; Bojovic, S. 2007. The ecological potential of Spiraea vanhouttei (Briot.) Zabel for urban (the city of Belgrade) and fly ash deposit (Obrenovac) landscaping in Serbia, Polish Journal of Environmental Studies 16: 427-431.

Salma, I.; Maenhaut, W.; Zemplén-Papp, É.; Záray, G. 2001. Comprehensive characterization of atmospheric aerosols in Budapest, Hungary: physicochemical properties of inorganic species, Atmospheric Environment 35: 43674378 .

Sawidis, T.; Breuste, J.; Mitrovic, M.; Pavlovic, P.; Tsigaridas, K. 2011. Trees as bioindicators of heavy metal pollution in three European cities, Environmental Pollution 159: 35603570 .
Temesi, D.; Molnár, Á; Mészáros, E.; Feczkó, T. 2003. Seasonal and diurnal variation in the size distribution of fine carbonaceous particles over rural Hungary, Atmospheric Environment 37: 139-146.

Wolterbeek, B.; Sarmento, S.; Verburg, T. 2010. Is there a future for biomonitoring of element air pollution? A review focused on a larger-scaled health-related (epidementological) context, Journal of Radioanalytical and Nuclear Chemistry 24: 926-934.

Youssef, N. A. 2012. Environmental monitoring of trace elements in leaves of Ligustrum japonicum L. by X-ray fluorescence (EDRF), in Proc. of the International Scientific Conference on Innovation Problems of Modern Biology, Baku, Azerbaijan.

Naglaa YOUSSEF. MSc (Botany, 2009). Pre-Master Diploma in Plant Ecology (October 2005). BSc Honours (Botany, June 2003), Botany Department, Faculty of Science, Sohag University, Egypt. Currently, Assistant Lecturer (2009) and Demonstrator (full-time; April 2005) in the Botany Department, Faculty of Science, Sohag University, Egypt. Research interests: plant ecology, plant community; air pollution; biomonitoring; biodiversity information systems; plant ecophysiology and plant responses to climate changes.

Bernd MARKERT. Professor, Dr Habil, Natural Scientist. Studies in Chemistry and Biology, Ludwig Maximilian University of Munich, Germany. PhD in 1986 and Habilitation for Ecology in 1993 at the University of Osnabrueck, Germany. Former Head of the International Graduate School, Germany, and Professor for Environmental High Technology. Member of the "Environmental Institute of Scientific Networks" (EISN-Institute.de), Haren, Germany. Publications: author/coauthor of about 400 scientific papers and 25 scientific books were authored/coauthored, edited or coedited. Research interests: biochemistry of trace substances in the water/soil/ plant system; instrumental analysis of chemical elements; developing the "Biological System of the Elements"; eco- and humantoxicological aspects of hazardous substances; pollution control by use of bioindicators and technologies for waste management, environmental restoration, and remedial action on soils; different interdisciplinary working fields in between natural, economic and social sciences; developing of an Ethical Consensus as smart method of conflict management which provides integrative solutions of problems; modelling Dialogic Education Processes (DEP) as a future principle of communication; attempt on integration of religious and scientific laws in relation to each other under specific consideration of mental and psychological influences or effects.

Elshad GURBANOV. Professor, Dr Biological Science, Chairman of the Botany Department of Biology, Baku University. Graduated in 1979 at the Faculty of Biology, Baku State University. During 1982-1992 worked as a Teacher and an Associate Professor at the chair of Botany, Baku State University; since 1992 a Chairman of Botany, Chair of Biology Faculty, Baku State University. Member of Central Election Commission from 2000 to 2002. Teaching lessons: systematization of supreme plants, ecology of plants, geobotany, bases of botany, and local flora. Author of 150 scientific publications, 2 monographs, and 5 books. Research interests: systematic of supreme plants; geobotany; and plant ecology.

Haciyeva SEVNIC. Dr, Chemistry Professor, the Head of Ecological Chemistry Sub Department, Baku State University. She worked at the Chemistry Department (1983), Baku State University, and graduated in 1988 with honours diploma. During 1989-1993 she was a postgraduate student of the Institute of Chemical Problem NASA. In 2003, won a prize of Y. Mammadaliev. During 2006-2007, won a prize and a honorary title of "Head of sub department of the year". From 1995 to 2004 was Senior Lecturer of the Chemistry Department. Since 2004 she is the Head of Ecological Chemistry Sub Department. Teaching lessons: general ecology, ecological chemistry, ecology and protection of the environment, and physical chemical parameters of the environment. Author of over 200 scientific publications: 70 articles, 6 books, 12 patents, 3 PhD. Research interests: investigation of chelate sorbents by spectrophotometric method for analyzing inorganic compounds; techniques of determination of ions by spectrophotometric methods; and monitoring the environment.

Simone WÜNSCHMANN. PhD, Natural Scientist and a former Scientific Assistant at the International Graduate School, Germany, Department of Environmental High Technology, Working Group for Human and Ecotoxicology. Diploma Engineer for Ecology and Environmental Protection, University of Applied Sciences, Germany. PhD in Environmental Sciences, University of Vechta, Germany. Member of the "Environmental Institute of Scientific Networks" (EISN-Institute.de), Haren, Germany. Publications: author/co-author of about 40 scientific papers and 4 scientific books. Participant at more than 50 international conferences. Research interests: pollution control, human and ecotoxicology; ecology and environmental protection; and environmental engineering with an emphasis on renewable energy. 